\title{
Research on the Credit Management of Commercial Banks of Lianyungang City for the SMEs
}

\author{
Chen Junyi \\ Business School \\ Huaihai Institute of Technology \\ Lianyungang, 222005, China \\ xizf98@126.com
}

\author{
Shuping Han \\ Business School \\ Huaihai Institute of Technology \\ Lianyungang, 222005, China \\ hansp@hhit.edu.cn
}

\begin{abstract}
At present, the credit management mode of commercial bank in lianyungang for the SMEs is still in the exploring, although the various credit policy for the small and medium-sized enterprises has been come out, the risk management plan and operation method that really suit for credit demand for the SMEs is still not mature. and it caused that the bad debts and dead loan were overstoched in lianyungang commercial bank, thus it seriously impact on the capital operation of commercial banks, and then it has caused some adverse impact to the development of local economy. Therefore, it is necessary for commercial banks in lianyungang city to supervise and manage the whole process of credit of the small and medium-sized enterprises.
\end{abstract}

Keywords- credit management, countermeasures, commercial banks, the SMEs

\section{INTRODUCTION}

Along with the quickening of the process of enterprise shareholding system reform and privatization in our country, in lianyungang city many small and medium-sized enterprises (SMEs)have become the main body and an important support force of its economic development ,and have made a great contribution for the development of local economy.

At the same time, commercial Banks in lianyungang have made their own contribution for small and medium enterprises in credit financing. By the end of 2011, the commercial bank in lianyungang city had already provided a loan of 24.926 billion yuan for SMEs, they abtained many profits meanwhile also promoted the development of small and medium businesses in the region. Because there is a lack of perfect risk early warning and information feedback system to small and medium enterprises in lianyungang commercial bank, so as to cause the information asymmetry between the two, commercial banks can not correctly assess the operating status of the small and medium-sized enterprises, and it caused that the bad debts and dead loan were overstoched in the lianyungang city commercial bank, thus it seriously impact on the capital operation of commercial banks, and then it has caused some adverse impact to the development of local economy. Therefore, whether in financial environment for economic development or in credit risk management of commercial banks, the research on credit management for small and medium-sized enterprises in lianyungang city commercial banks has the extremely vital significance [1].

\section{EXISTING CREDIT MANAGEMENT PROBLEMS OF} COMMERCIAL BANKS OF LIANYUNGANG FOR THE SMES

A. As information is asymmetry, the commercial banks are not willing to loan to the SMEs

For small and medium-sized companies, its inherent characteristics of demanding for loans decided that the commercial banks in the credit management on the access policy had some of the pertinence and particularity, which had very big distinction from large enterprises and other different nature of the enterprises.

However, at present, the credit management mode of commercial bank in lianyungang city for small and medium enterprises is still in the exploring, although the various credit policy for the small and medium-sized enterprises has been come out, the risk management plan and operation method that really suit for credit demand for small and medium-sized enterprise is not mature, which is not certain whether suit for the small and medium-sized enterprises, so commercial bank can't loan to the small and medium enterprises at random, and worry about them that can't timely repay loan. Thus, owing to some factors, such as loans management system of commercial banks in lianyungang city did not correspond with loan demands of the small and medium-sized enterprises, and the commercial banks had increased risk prevention consciousness after the financial crisis, the commercial bank in lianyungang city provided less and less loan to the small and medium enterprises, and began to tighten money policy and increase the loan interest rate [2].

From the Fig.1 it can be seen that, from 2002 to 2011 year, the total loan amount of commercial bank in lianyungang city for all kinds of enterprises showed a rising trend. Especially in 2009, it achieved 231.568 billion yuan. Especially after the financial crisis, as the all kinds of enterprise had been attacked more or less by the financial crisis, they needed a lot of capital to maintain business, therefor, in this case total loans of many enterprises applying for commercial banks rised faster. But from the Fig.1 it can be see that loans provided by commercial banks for the small and medium enterprises reduced year after year, which is 
only about a third of loan amount for large enterprises. It shows that, considering repayment loan ability of the small and medium-sized enterprises in the financial crisis, commercial Banks in lianyungang city provided less and less loans for the small and medium enterprises so as to lead to " stint loans " phenomenon [3].

\section{B. Commercial banks lack of sound credit policy and system aiming at the SMEs}

As commercial banks in Lianyungang city paid more attentin to the large enterprises, it leads that the majority of credit policies formulated by them only aimed at the large and medium-sized enterprises, but for credit management to the small and medium-sized enterprise, commercial banks isn't aggressive enough. As lack of understanding of various loan demands from the small and medium-sized enterprises, although commercial banks had formulated many credit policy and product aiming at the SMEs, which were still not mature and had many defects. So this results that current credit policy formulated by commercial banks in lianyungang city for the SMEs is not completely accord with the characteristics of small and medium-sized enterprises [4].

From the Fig.2 it can be seen that, in 2011, loan of the small and medium-sized enterprises in lianyungang involved in numerous areas, such as industry, business, agriculture, construction, etc, whose relationships are smaller each other and characteristics are diffrent. Therefore, because of credit characteristics and uses of the small and medium-sized enterprises are changeful and complex, it results that the credit loan product of commercial banks in lianyungang city for small and medium-sized enterprises are still imperfect [5].

\section{Commercial banks lack of perfect system of risk warning and feedback information aiming at the SMEs credit}

For commercial banks in Lianyungang, especially some city-owner commercial banks, their main loan object is numerous small and medium-sized enterprises, but credit management of commercial Banks for them is more relatively weak than large companies. Although various commercial Banks have stipulated theoretically all kinds of action plan of the risk warning, but in fact, because setting early-warning index is unreasonable and the corresponding transmission mechanism is lack, it results that the effect of risk warning is little. The specific performance is lack of reasonable and effective risk warning index and smooth risk warning feedback transmission mechanism, which leads that the warning is lag [6].

As shown in Table 1, the withdrawal ratio of loans funds of commercial bank to small and medium-sized enterprises is generally relatively low in Lianyungang, especially since the financial crisis in 2007, the return ratio of loan is more and more low, and each year almost half of the funds couldn't be returned on time.Thus it can be seen that the supervision system for withdrawal of loans of commercial banks to small and medium-sized enterprise is imperfect in Lianyungang, which could greatly impact on capital operation of the commercial banks, thus restrict the economic development in Lianyungang.

\section{Commercial banks didn't deal with perfectly the problems of escaping debts of the SMEs}

From the figure 3 it can seen that, since 2002, the amount of the bad debts and dead loans of commercial banks in lianyungang city had been rising. Especially since the financial crisis in 2007, the amount had increased rapidly, which reached the maximum in 2009 and was 1.102 billion yuan. Therefore, as commercial banks didn't deal with perfectly the problems of escaping debts of the small and medium-sized enterprises, and can not recover many funds in time, so as to result in capital loss of the commercial banks and seriously impacting on capital operation of the commercial bank, and then it had caused some negative effects to the development of local economy [7].

\section{COUNTERMEASURES OF CREDIT MANAGEMENT OF COMMERCIAL BANKS IN LIANYUNGANG FOR THE SMES}

\section{A. Establishing the credit culture with the control risk as} the core.

Good risk management culture could contribute to strengthen the communication and cooperation between managements and employees, thus help commercial Banks achieve its credit development goals. So building good credit culture has become the realistic choice of commercial Banks in lianyungang city in the future development and competition. The commercial banks should strengthen market risk awareness on their own, and establish and perfect the early warning mechanism for risk, so as to strengthen the risk responsibility consciousness and team cooperation spirit of the internal managements [8].

\section{B. Building new relationship between banks and enterprises and improving information asymmetry phenomenon.}

The commercial banks should strengthen investigation and analysis of the comprehensive information of the SMEs, including financial status and capital operation, and know comprehensively the financial situation and ability to repay loan of the SMEs, and select the SMEs with high credit standing, normal business management and broad market prospect as long-term partners so as to lower their credit risk [9].

\section{Perfecting the faithless punishment mechanism.}

Commercial banks should establish and perfect the faithless punishment mechanism for the SMEs. Commercial Banks may release regularly credit information of the small and medium-sized enterprises on the net, and publish timely credit condition of the small and medium enterprises, especially set up overall warning system for bad credit covering the SMEs in full county range. They should punish the faithless enterprises, according to the faithless degree, 
and different loss, by the relevant provisions. At the same time, by playing the role of the trade association, various commercial banks should strengthen contact and share information so as to promote credit construction of the financial industry [10].

\section{Strengthen the ability to monitor the loan risk.}

For the small and medium-sized enterprises, commercial bank should assess their credit risk, including business operations, financial situation, mortgage assets and credit status, and provide loans for them within the limits of manageable risk, so as to ensure the safety of the loans. Furthermore, commercial bank should further analyze and master the current macroeconomic situation, and form prediction for the influence of macro economic change on the credit industry, so that take timely measures for bad economic development, and set up a corresponding risk emergency mechanism so as to avoid unnecessary loss [11].

\section{CONCLUSION}

At present, the credit assets quality of commercial bank impacted directly on the survival and development of itself. It is the focus of the current credit working, including improving the credit management mode, increasing the quality of loan assets and guarding against credit risk. In order to improve the current situation of credit management of commercial bank in lianyungang city to the small and medium-sized enterprises, and form good credit management mode so that promote benign operation of credit management, it is necessary for commercial banks in lianyungang city to supervise and manage the whole process of credit of the small and medium-sized enterprises. Therefore, it has very important practical significance for the commercial banks of lianyungang to research the problems and countermeasures credit management to the SMEs.

\section{REFERENCES}

[1] A.Sinan Cebenoyana,Philip E Strahan. Risk management, capital structure and lending at banks. Journal of Banking \& Finance. Volume 28, Issue 1, January 2004, P.19-43

[2] Allen N. Berger, Robert DeYoung. Problem loans and cost efficiency in commercialbanks. Journal of Banking \& Finance. Volume 21, Issue 6, June 1997, P.849-870.

[3] J.R.Qiu, Credit Business of Commercial Bank. Beijing: China financial Press (2009).

[4] X.Y.Wan, Implementation Situation of New Loan Rules of Commercial Bank, Jlogistics Engineering and Management, 2011.2, p.108-110.

[5] X.L.Zhang, Characteristics and Control of Credit Risks of Commercial Bank for Group Customer, Financial Teaching and Research, 2011.3, p.45-48

[6] J.Y. Liu, G.Yu, Research on Structure Characteristics of Credit Response to Monetary Policy in Commercial Bank, Research on Financial and Economic Questions, 2009.11, p.81-87.

[7] H.L.Zhang, Research on Bank Credit Risk Assessment and Prevention of Small-and-Medium-Sized Enterprises of Zhejiang Province, Chinese finance, 2008.5, p.51-61.

[8] H.C. Chen, Y.Y. Wu, Internal Control System and Improvement Strategy of Operational Risk in Commercial banks, Accounting Monthly, 2008.6, p.45-49.

[9] Tang Guochu, Li Xuanju. Restructuring of the State-owned Commercial Banks in China. Journal of Finance, 2003.01, p.51-61.

[10] William F Treacy, Mark Carey. Credit risk rating systems at large US banks. Journal of Banking \& Finance, Volume 24, Issues 1-2, January 2000, P.167-201

[11] Marcia Millon Cornetta, Jamie John McNuttb, Philip E. Strahanc. Liquidity risk management and credit supply in the financial crisis. Journal of Financial Economics, Volume 101, Issue 2, August 2011, P.297-312

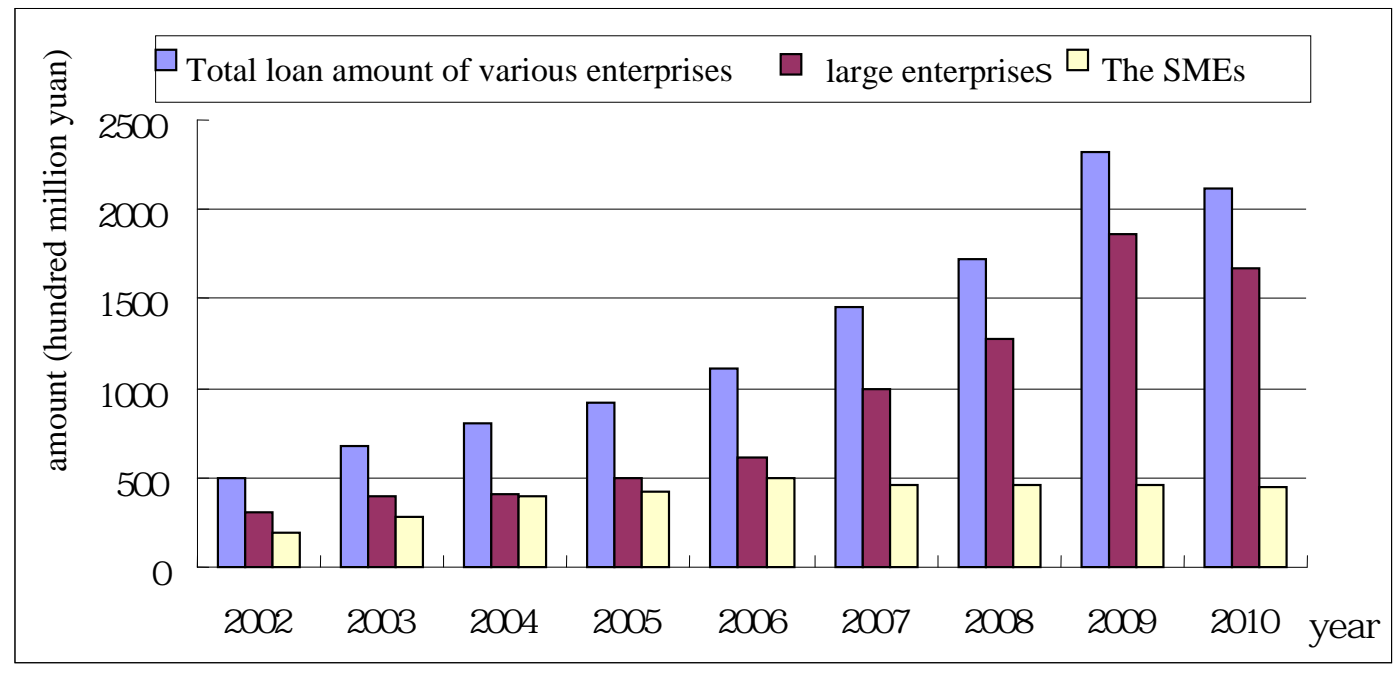

Figure 1. Total loan amount of the commercial bank in lianyungang city for various enterprises in 2002-2010 


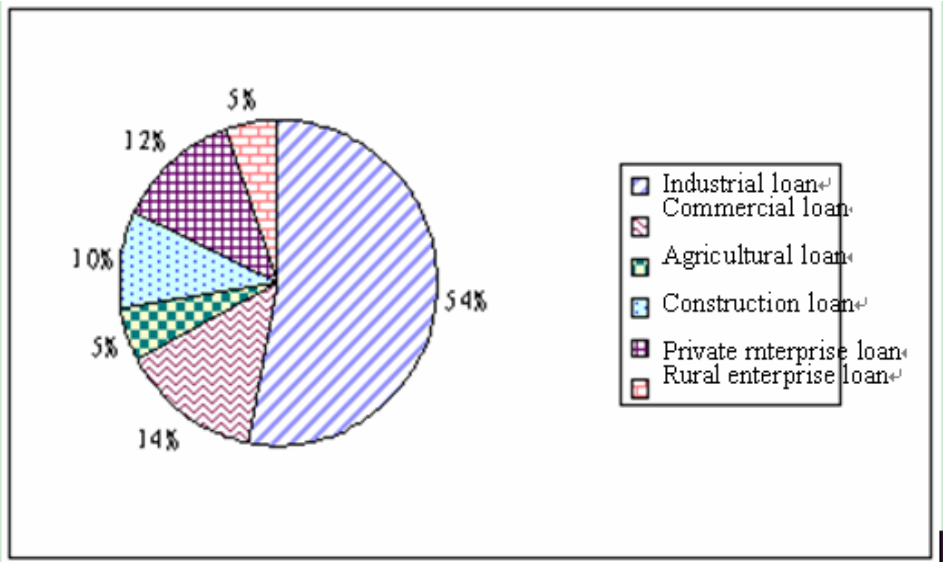

Figure 2. Loan usage of the SMEs in lianyungang city in 2011

TABLE I. WITHDRAWAL RATIO OF LOANS FUNDS OF COMMERCIAL BANK TO THE SMES IN LIANYUNGANG IN 2002-2010

\begin{tabular}{|c|c|c|c|c|}
\hline Year & Total loan amount & loan repayment & No return & Withdrawal ratio \\
\hline 2002 & 193.49 & 123.45 & 70.04 & $63.80 \%$ \\
\hline 2003 & 279.26 & 217.35 & 61.91 & $77.83 \%$ \\
\hline 2004 & 396.3 & 259.76 & 136.54 & $66.55 \%$ \\
\hline 2005 & 423.92 & 368.10 & 55.82 & $86.83 \%$ \\
\hline 2006 & 499.37 & 401.03 & 98.34 & $80.31 \%$ \\
\hline 2007 & 461.99 & 306.11 & 155.88 & $66.26 \%$ \\
\hline 2008 & 458.26 & 245.96 & 212.30 & $53.67 \%$ \\
\hline 2009 & 459.45 & 279.13 & 180.32 & $60.75 \%$ \\
\hline 2010 & 449.26 & 267.37 & 181.89 & $59.51 \%$ \\
\hline
\end{tabular}

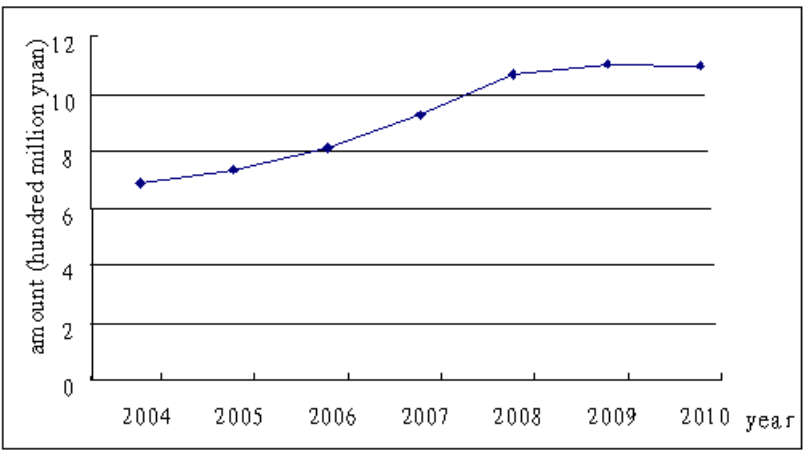

Figure 3. Amount of the bad debts and dead loans of commercial banks in lianyungang in 2004-2010 